See discussions, stats, and author profiles for this publication at: https://www.researchgate.net/publication/327000678

\title{
Gap between MOOC Designers' and MOOC Learners' Perspectives on Interaction and Experiences in MOOCs: Findings from the Global MOOC Quality Survey
}

Conference Paper · July 2018

DOI: 10.1109//CALT.2018.00007

\section{CITATIONS}

12

7 authors, including:

Christian M. Stracke

Open Universiteit Nederland

66 PUBLICATIONS 370 CITATIONS

SEE PROFILE

Antonio Moreira Teixeira

Universidade Aberta

38 PUBLICATIONS 324 CITATIONS

SEE PROFILE

Some of the authors of this publication are also working on these related projects:

Project MOOQ- Massive Online Open Quality Education View project

Project Learning Innovations and Learning Quality (LINQ) View project
READS

325

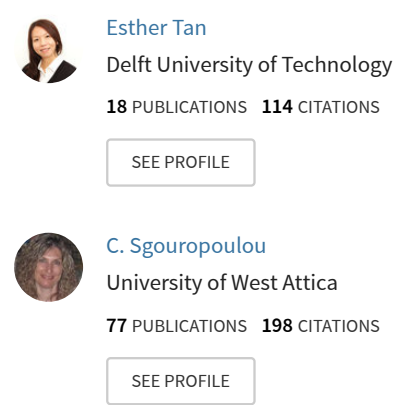


Christian M. Stracke et al.

Gap between MOOC designers' and MOOC learners' perspectives on interaction and experiences in MOOCs:

Findings from the Global MOOC Quality Survey

www.opening-up.education 


\title{
Gap between MOOC designers' and MOOC learners' perspectives on interaction and experiences in MOOCs: Findings from the Global MOOC Quality Survey
}

\author{
by Christian M. Stracke et al. (2018)
}

Citation:

Stracke, C. M., Tan, E., Texeira, A. M., Pinto, M., Kameas, A., Vassiliadis, B., \& Sgouropoulou, C. (2018). Gap between MOOC designers' and MOOC learners' perspectives on interaction and experiences in MOOCs: Findings from the Global MOOC Quality Survey. In M. Chang, N.S. Chen, R. Huang, Kinshuk, K. Moudgalya, S. Murthy, \& D. G. Sampson (Eds.), Proceedings 18th IEEE International Conference on Advanced Learning Technologies (ICALT) (pp. 1-5). IEEE: Computer Society. DOI 10.1109/ICALT.2018.0000

[also online available at: http://www.opening-up.education

and at: http://dspace.ou.nl DOI: http://hdl.handle.net/1820/9900]

\section{Contact:}

Dr. Christian M. Stracke

ICDE Chair in OER

Associate Professor for Open Education and Innovation

Open University of the Netherlands

Adjunct Professor, Korean National Open University

Advisory Professor, East China Normal University

http://www.ou.nl/web/welten-institute

Christian.Stracke@OU.NL

http://www.opening-up.education

http://www.learning-innovations.eu

http://www.ICORE-online.org

(C) Christian M. Stracke

This article is published under the Creative Commons licence "BY-NC-ND 4.0" (Attribution - Non-Commercial - No Derivate 4.0).

The full licence (legal code) can be read online here:

<http://creativecommons.org/licenses/by-nc-nd/4.0/legalcode>

You are free to share the work, i.e. to copy and redistribute the material in any medium or format, under the following conditions:

1. Attribution -

2. NonCommercial -

3. NoDerivates 


\section{Gap between MOOC designers' and MOOC learners' perspectives on interaction and experiences in MOOCs: Findings from the Global MOOC Quality Survey}

\author{
Christian M. Stracke \\ Open University of the Netherlands, Heerlen \\ Korean National Open University, Seoul \\ East China Normal University, Shanghai \\ christian.stracke@,ou.nl \\ António Moreira Texeira \\ Universidade Aberta des Lisboa, Lisbon \\ antonio.teixeira@uab.pt \\ Bill Vassiliadis \\ Hellenic Open University, Patras \\ $\underline{\mathrm{bb} @ \text {,eap.gr }}$
}

\author{
Esther Tan \\ Open University of the Netherlands, Heerlen \\ esther.tan@,ou.nl \\ Maria do Carmo Texeira Pinto \\ Universidade Aberta des Lisboa, Lisbon \\ maria.pinto@uab.pt \\ Achilles Kameas \\ Hellenic Open University, Patras \\ kameas@eap.gr \\ Cleo Sgouropoulou \\ University of West Attica, Athens \\ cleo.sgouropoulou@gmail.com
}

\begin{abstract}
Massive Open Online Courses (MOOCs) became very popular during the last years leading to an increasing global debate about their quality. To address the quality issues, several research surveys and instruments were developed to analyse the current status of MOOCs and to examine the different perspectives of learning with MOOC from core MOOC stakeholders. Based on a literature review and analysis of existing quality approaches and indicators for MOOCs, the Global MOOC Quality Survey was designed and conducted $(n=267)$. Final objective is the development of the Quality Reference Framework (QRF) with quality indicators and tools in close collaboration with all interested stakeholders worldwide. This paper presents first results from the Global MOOC Quality survey relating to the overall experiences with MOOCs and their offered four interaction types: learnerfacilitator (LF), learner-resource (LR), learner-learner (LL) and group-group (GG). There was a very high significant relationship $(p<.001)$ between the learners' MOOC experience and the three interaction types $L F, L R$ and $L L$ and a significant relationship $(p=.026)$ for the fourth interaction type GG. There was not a significant relationship between the designers' MOOC experience and all four interaction types. Comparing the different perspectives of learners and designers, our analysis presents significant differences in MOOC learners' and designers' intentions and experiences. Hence, it can be questioned whether MOOC designers are currently understanding and meeting the interests and demands of the MOOC learners.
\end{abstract}

Keywords-MOOCs, learners, designers, interaction types, learning experiences, design experiences, Global MOOC Quality Survey

\section{INTRODUCTION}

The societies and their economies, working and living conditions are facing global challenges and changes. They are affecting all parts of our lives including the ways how we learn and educate [14]. Even though that the individual process of learning is not changing completely, the circumstances and modes of learning and education are becoming more diverse [21]. In particular, the educational systems are challenged by transforming objectives and development targets to innovate and opening up education [17] [21] [13]. Citizens have to acquire and develop much different skills and competences due to competing businesses and interests at national, regional and international scales are demanding for new work forces [5]. It is claimed that new economies and jobs are emerging that are not yet existing or fully developed and public education should prepare for it by personality and competence building. On the other hand, there are also considerable changes in the individual lives and work conditions, not only related to labour market opportunities and increasing workload pressure, but also regarding individual communication, collaboration and online learning [26].

All these societal, educational and personal changes have led to the increasing awareness amongst stakeholders at all educational levels of the growing importance of Open (Online) Education [5]. Global grass-root movements, events, communities and associations and international policies and implementations in national and regional educational systems were successfully created and sustained. Major milestones were the UNESCO declarations on Open Education and in particular the policy on Open Educational Resources (OER) [24]. In Europe, the European Commission 
is supporting it by the communication on "Opening Up Education" [4] demanding a change in education and society. Within Open Online Education the phenomenon MOOC (short for: Massive Open Online Courses) became very popular [19]: The first MOOC was provided in the year 2008 and since then, the number of MOOCs has been constantly growing [6]. A first peak could be discovered in the year 2012 that was labeled as the "Year of the MOOCs" [1]: It sparked off a debate questioning the quality of MOOCs and their educational value as learning experience and educational tool which has continued till today. Nevertheless the number of MOOCs $(9,400)$, MOOC learners (81 Mio.) and providers $(800+)$ is continuously booming also in 2017 as reported by Class Central [19].

\section{DESIGN AND QUALITY OF MOOCs}

The quality of MOOCs and online learning and education in general has been a recurring theme in current discourse on MOOCs. The drop-out rates are the typical measure in traditional distance education courses and in all formal education settings: They are discussed in MOOCs as their completion rates are very low and often below $10 \%$ [3] [8]. Therefore, the demand for re-booting the design of MOOCs and their research and quality gained increasing attention and new research agenda were claimed [10] [18]. However, this discussion of low quality MOOCs is mainly based on an improper use of drop-out rates as a formal evaluation measure of face-to-face education. This is problematic as MOOCs engender mostly non-formal learning experiences [15]. Thus, alternative evaluation measures have been proposed for MOOCs to better address learners and their personal intentions and goals in learning with MOOCs [9] [22]. To focus on the quality issue, the development of a Quality Reference Framework (QRF) for MOOCs was envisaged and started: An international alliance was established to connect and bring together key experts and organizations to collaboratively address the quality of open online learning and education and, in particular, MOOCs.

The importance of interactions for learning processes is highlighted from the beginning of education such as in Socrates' critical dialogue, Rousseau's social contract with the society, Piaget's cognitive exploration of the surrounding environment, Vygotsky's zone of proximal development with guidance, Dewey's focus on experiments and communication and Luhmann's relationship of human beings to the external environment as observers second order.

Several studies have reported significant relationships and positive effects of interactions in online learning and in particular in MOOCs [23]: Interactions with content lead e.g., to better results [27] and higher perceived quality of online courses [16]. Interactions with other learners in online courses support e.g., the satisfaction [20] and perceived effectiveness [12]. However there is no broad research on interactions with facilitators of MOOCs as MOOCs are often not offering the facilitation of such direct interactions.

For our vision and objective to improve the future MOOCs, we have modified and expanded the concept of Moore [11] distinguishing between three interaction types: learner-instructor (LI), learner-content (LC) and learner- learner (LL). As MOOCs target and involve masses, educational tasks are often realized in teams and groups of learners: Therefore we have added a fourth interaction type leading to our distinction of these four interaction types: learner-facilitator (LF), learner-resource (LR), learnerlearner (LL) and group-group (GG) as fourth type for interactions among different groups of learners.

This paper presents the first results from our research activities to improve the quality of future MOOCs focusing on the interaction types and the different perspectives from MOOC learners and designers. Thus it allows an insight into the future QRF development and the further challenges and tasks.

\section{The GLOBAL MOOC QUALITY SURVEY}

To address the quality issues and to facilitate the QRF development, several research surveys and instruments with different theoretical and methodological approaches were developed and combined. They serve to analyse the current status of MOOC and explore different perspectives from core stakeholders of MOOC. First, an in-depth literature review and analysis of existing quality approaches, evaluation instruments and quality indicators for MOOCs were conducted and their findings are under publication.

Based on findings from the literature review and analysis of quality approaches, the Global MOOC Quality Survey was prepared and designed in two steps: First, a small presurvey with a set of potential questions was developed and administered. The pre-survey respondents $(n=45)$ showed that many MOOC learners do not share the same intentions with the MOOC designers. Next, the Global MOOC Quality Survey was developed for three target groups: learners, designers and facilitators of MOOCs. It was conducted with the support and dissemination of the leading international associations and institutions and over a period of four months in the year 2017 as an open online survey. Table I presents an overview of the number of survey participants from the three target groups: As expected, the number of MOOC learners was highest but the number of designers is still sufficient for comparison.

\section{TABLE I. PARTICIPANTS OF GLOBAL MOOC SURVEY}

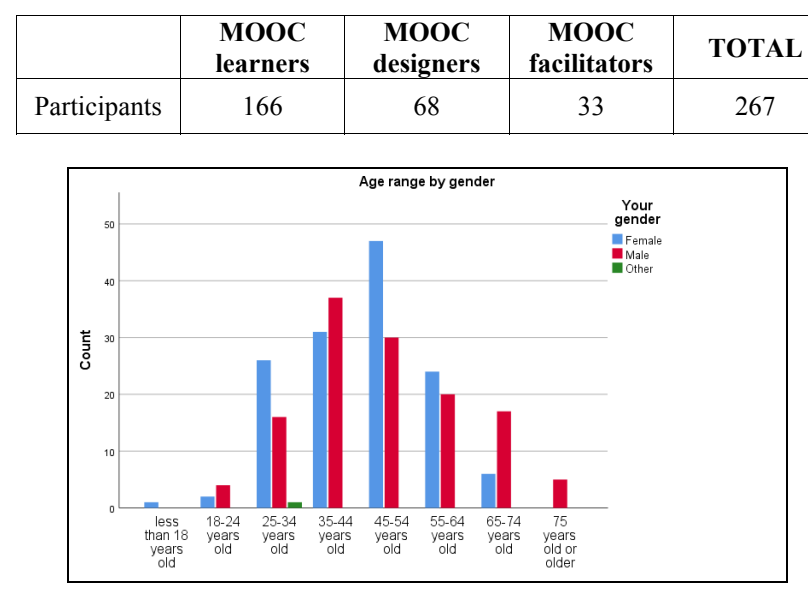

Figure 1. Age of survey participants by gender 


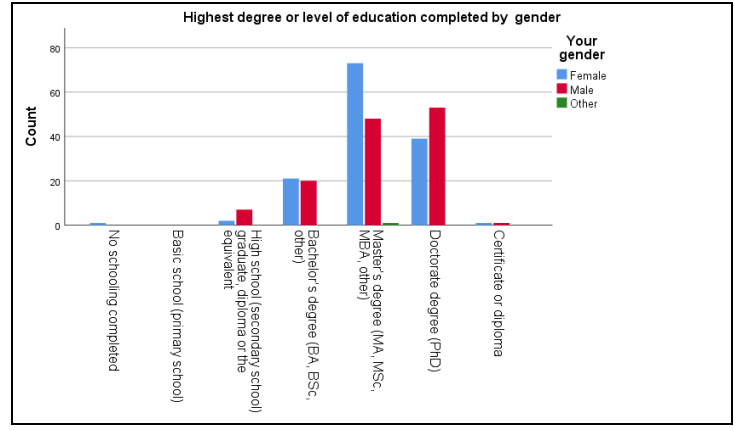

Figure 2. Education of survey participants by gender

Fig. 1 and fig. 2 show the age and highest education of the survey participants. The female participants are younger and reporting a lower level of highest education what is not surprising and in line with their lower age. The age range presents a normal distribution, also compared with MOOC and average populations, whereas the educational level is very high in relation to the average population but very similar to the reported MOOC populations [2] [7]. Both groups of participants are coming from all five continents with a majority from Europe but still balanced.

\section{RESULTS ON INTERACTIONS AND EXPERIENCES}

The findings from the Global MOOC Survey on the MOOC designers' and MOOC learners' perspectives on interaction and experiences in MOOCs are described below.

General findings on the designers' and learners' experiences in MOOCs are as follows:

Most of the 267 survey participants from the three target groups reported positive experiences with MOOCs. However the rating of the experience with MOOCs varied across the two target groups: MOOC learners and MOOC designers.

Table II and fig. 3 show the responses of the learners on their learning experience (question item LLE4)

TABLE II. ANSWERS ON LEARNING EXPERIENCE LLE4 BY LEARNERS

\begin{tabular}{|l|c|c|c|c|c|c|}
\hline & $\mathbf{n}$ & VB & B & N & G & VG \\
\hline $\begin{array}{l}\text { Learning } \\
\text { experience }\end{array}$ & 166 & 4 & 4 & 13 & 75 & 70 \\
\hline \multicolumn{6}{|c|}{ VB: Very Bad, B: Bad, N: Neutral, G: Good, VG: Very Good }
\end{tabular}

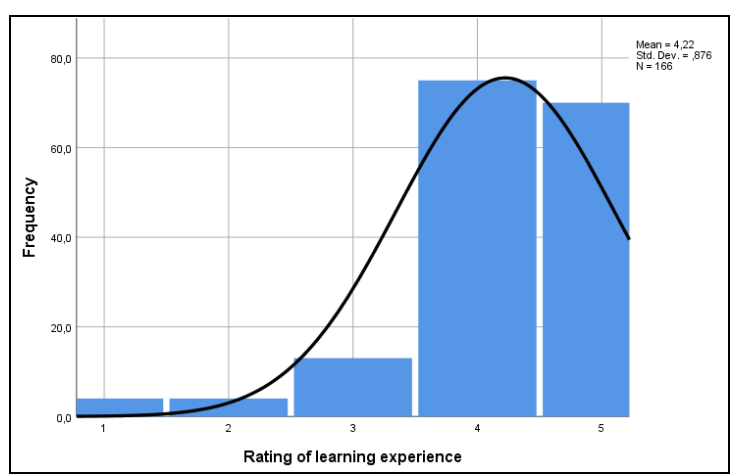

Figure 3. MOOC learning experiences by learners
Table III and fig. 4 show the responses of the designers on their design experience (question item DDE4)

TABLE III. ANSWERS ON DESIGN EXPERIENCE DDE4 BY DESIGNERS

\begin{tabular}{|l|c|c|c|c|c|c|}
\hline & $\mathbf{n}$ & VB & B & N & G & VG \\
\hline $\begin{array}{l}\text { Design } \\
\text { experience }\end{array}$ & 68 & 1 & 2 & 13 & 33 & 19 \\
\hline
\end{tabular}

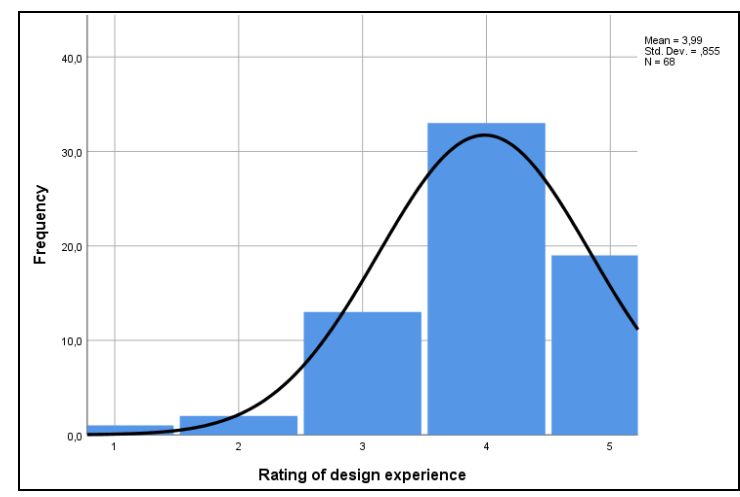

Figure 4. MOOC design experiences by designers

The learners gave high rates when asked about their learning experience in a MOOC. The designers rated their experiences worse when compared to the learners on their learning experience. We attribute this to the challenges they faced in their design experience. Here our interpretation is that they may underestimate their design work and results leading to lower rates for their design experiences in comparison with the learners' experiences. There is a clear but not significant difference. Future in-depth and regression analysis on the other data and multi-dimensional correlations will explore all relationships in greater detail.

Specific findings from the Global MOOC Quality Survey on designers' and learners' perspectives on interaction and in correlation to their experiences in MOOCs are as follows:

Next, we investigate the perspectives on the (intended) MOOC interactions as foreseen by the designers and the (real) MOOC interactions as reported by the learners.

Table IV shows the learners' responses on the experienced interactions in MOOCs (LF, LL, LR and GG = question items LLR4-1 to LLR4-4).

TABLE IV. ANSWERS ON INTERACTION ITEMS LLR4 BY LEARNERS

\begin{tabular}{|l|c|c|c|c|c|c|c|}
\hline & $\mathbf{n}$ & N/A & SD & D & N & A & SA \\
\hline $\begin{array}{l}\text { LF by } \\
\text { learners }\end{array}$ & 146 & 20 & 5 & 13 & 48 & 37 & 23 \\
\hline $\begin{array}{l}\text { LL by } \\
\text { learners }\end{array}$ & 146 & 15 & 3 & 17 & 34 & 51 & 26 \\
\hline $\begin{array}{l}\text { LR by } \\
\text { learners }\end{array}$ & 146 & 9 & 2 & 8 & 25 & 61 & 41 \\
\hline $\begin{array}{l}\text { GG by } \\
\text { learners }\end{array}$ & 146 & 37 & 4 & 15 & 50 & 24 & 16 \\
\hline
\end{tabular}

N/A: Not available, SD: Strongly Disagree, D: Disagree, N: Neutral, A: Agree, SA: Strongly Agree 
Table V shows the bivariate correlations between the learners' interactions (LLR4 items as predictors) and learners' experiences (LLE4 as outcome). The calculated $n$ is (n-1) of all answers on the respective LLR4 items due to freedom of choice.

TABLE V. BIVARIATE CORRELATIONS BETWEEN LLR4 AND LLE4

\begin{tabular}{|l|c|c|c|c|}
\hline & $\mathbf{n}$ & $\mathbf{R}^{\mathbf{2}}$ & $\mathbf{M}^{\mathbf{2}}$ & $\boldsymbol{p}$ \\
\hline $\begin{array}{l}\text { LF by } \\
\text { learners }\end{array}$ & 125 & .094 & 9.382 & $.000^{* * *}$ \\
\hline $\begin{array}{l}\text { LL by } \\
\text { learners }\end{array}$ & 130 & .101 & 10.818 & $.000^{* * *}$ \\
\hline $\begin{array}{l}\text { LR by } \\
\text { learners }\end{array}$ & 136 & .112 & 12.286 & $.000^{* * *}$ \\
\hline $\begin{array}{l}\text { GG by } \\
\text { learners }\end{array}$ & 108 & .045 & 4.131 & $.026^{*}$ \\
\hline
\end{tabular}

The bivariate correlations do show very high significant relations between three of the four types of interaction and the learning experience (LLE4), namely LF (LLR4-1: "Interaction between learners and facilitators"), LL (LLR-2: "Interaction among learners") and LR (LLR4-3: "Interaction between learners and learning resources"), whereas there is no significant relation between GG (LLR4-4: "Interaction among teams and groups") and the learning experiences (LLE4).

In addition the coefficient of determination $\left(\mathrm{R}^{2}\right)$ measuring the substantive importance of an effect is very high for the three interaction types LF, LL and LR: They are sharing between $9 \%$ and $11 \%$ of the variation of the learning experience. And the fourth interaction type GG still shares $4.5 \%$ of the learning experience's variance. Further regression and multi-dimensional analysis has to clarify the amount how much the interaction types are causing variation of the learning experience.

Table VI presents the designers' responses on the designed interactions in MOOCs (LF, LL, LR and GG = question items DLR4-1 to DLR4-4).

TABLE VI. ANSWERS ON INTERACTION ITEMS DLR4 BY DESIGNERS

\begin{tabular}{|l|c|c|c|c|c|c|c|}
\hline & $\mathbf{n}$ & N/A & SD & D & N & A & SA \\
\hline $\begin{array}{l}\text { LF by } \\
\text { designers }\end{array}$ & 52 & 2 & 1 & 5 & 11 & 24 & 9 \\
\hline $\begin{array}{l}\text { LL by } \\
\text { designers }\end{array}$ & 52 & 1 & 1 & 3 & 11 & 19 & 17 \\
\hline $\begin{array}{l}\text { LR by } \\
\text { designers }\end{array}$ & 52 & 3 & 1 & 0 & 4 & 22 & 22 \\
\hline $\begin{array}{l}\text { GG by } \\
\text { designers }\end{array}$ & 52 & 8 & 2 & 10 & 14 & 13 & 5 \\
\hline
\end{tabular}

N/A: Not available, SD: Strongly Disagree, D: Disagree, N: Neutral, A: Agree, SA: Strongly Agree

Table VII presents the bivariate correlations between the designers' interactions (DLR4 items as predictors) and designers' experiences (DDE4 as outcome). The calculated $n$ is (n-1) of all answers on the respective DLR4 items due to freedom of choice.
TABLE VII. BIVARIATE CORRELATIONS BETWEEN DLR4 AND DDE4

\begin{tabular}{|l|c|c|c|c|}
\hline & $\mathbf{n}$ & $\mathbf{R}^{2}$ & $\mathbf{M}^{\mathbf{2}}$ & $\boldsymbol{p}$ \\
\hline $\begin{array}{l}\text { LF by } \\
\text { designers }\end{array}$ & 49 & .003 & 0.109 & .703 \\
\hline $\begin{array}{l}\text { LL by } \\
\text { designers }\end{array}$ & 50 & .043 & 1.595 & .143 \\
\hline $\begin{array}{l}\text { LR by } \\
\text { designers }\end{array}$ & 48 & .046 & 1.537 & .138 \\
\hline $\begin{array}{l}\text { GG by } \\
\text { designers }\end{array}$ & 43 & .001 & 0.038 & .821 \\
\hline
\end{tabular}

*: Significant $(p<.05),{ }^{* *}$ : High significant $(p<.01), * * *$ : Very high significant $(p<.001)$

The bivariate correlations do not present any significant relation between the four interaction types (LF, LL, LR and GG) and the design experience (DDE4) but the results are quite different for the two interaction types LL and LR and for the two interaction types LF and GG.

The coefficient of determination $\left(\mathrm{R}^{2}\right)$ measuring the substantive importance of an effect is quite high for the two interaction types LL and LR: They are sharing around $4.5 \%$. Further regression and multi-dimensional analysis has to clarify the amount how much the interaction types are causing variation of the learning experience. The other two interaction types LF and GG only share $0.3 \%$ resp. $0.1 \%$ of the design experience's variance and it can be claimed that they are not causing any effect on the design experience.

\section{COMPARISON OF LEARNERS' AND DESIGNERS' PERSPECTIVE ON INTERACTION}

The comparison of the correlations from the learners' and designers' answers surfaced some noteworthy findings. First, it seems that their perspectives on the importance of at least three of the four interaction types are very contradictory. There is consensus on the fourth interaction type (GG) as the $p$ value is the lowest for both, learners and designers, i.e. no direct relation can be demonstrated. Among the three interaction types with very high significant relations for the learners, two interaction types (LL and LR) have a much lower $p$ value, i.e. a small relationship could exist for the designers whereas it is excluded for the other interaction type (LF) with $p=.703$ : In general it is surprising that designers do not value interaction as much as the learners what could lead to MOOC designs not fitting the interests and demands of the learners. Further regression and multi-dimensional crosscorrelation analysis has to be realized to provide more indepth results. Finally it can be stated that the Global MOOC Quality Survey based on the combination of different research instruments seems to provide a multi-dimensional overview of the intentions and experiences across the different MOOC stakeholders.

\section{CONCLUSION AND OUTLOOK}

This paper presents the first findings from the Global MOOC Quality Survey with a focus on the MOOC designers' and MOOC learners' perspectives on interaction and experiences in MOOCs:

On the experience of learners and designers with MOOCs, specifically, we were interested to compare the 
learners' and designers' perspective on interaction in learning with MOOCs. The designers underestimated their design work as the MOOC learners gave higher ratings for their learning experience. And on the aspect of interaction, there were significantly huge differences between MOOC learners and MOOC designers related three of four interaction types. There was a very high significant relationship $(p<.001)$ between the learners' MOOC experience and the three interaction types LF, LR and LL and a significant relationship $(p=.026)$ for the fourth interaction type GG. There was not a significant relationship between the designers' MOOC experience and all four interaction types.

Comparing the different perspectives of learners and designers, our analysis presents significant differences in MOOC learners' and designers' intentions and experiences. The correlation differences of the MOOC learners and designers on the interaction in MOOCs are significantly very high: We attribute this to the gap between MOOC designers' and MOOC learners' perspectives on interaction in MOOCs. MOOC designers do not seem to understand very well the needs and demands of MOOC learners. This leads us to conclude that it can be questioned whether designers currently understand and meet the needs and demands of MOOC learners.

Our vision is to improve and to foster the quality in Open Online Education and Learning and in particular in MOOCs that it will lead us to a new era of learning experiences. This paper is a first small step towards the ambitious objective of developing a Quality Reference Framework (QRF) to facilitate and support better design and delivery of MOOCs for the benefit of all MOOC learners worldwide.

\section{ACKNOWLEDGMENT}

This article is supported by MOOQ, the European Alliance for Quality of Massive Open Online Courses (www.MOOC-quality.eu). The vision of MOOQ is to foster quality in MOOCs leading to a new era of learning experiences. MOOQ is funded by the European Commission under the project number: 2015-1-NL01-KA203-008950.

\section{REFERENCES}

[1] Daniel, J (2012). Making Sense of MOOCs: Musings in a Maze of Myth, Paradox and Possibility. [see: http://sirjohn.ca/wordpress/wpcontent/uploads/2012/08/120925MOOCspaper2.pdf]

[2] Dillahunt, T. R., Wang, B. Z., \& Teasley, S. (2014). Democratizing higher education: Exploring MOOC use among those who cannot afford a formal education. The International Review of Research in Open and Distributed Learning, 15(5), pp. 1-20.

[3] Evans, B. J., Baker, R. B., \& Dee, T. S. (2016). Persistence patterns in Massive Open Online Courses (MOOCs). Journal of Higher Education, 87(2), 206-242. http://dx.doi.org/10.1353/jhe.2016.0006.

[4] European Commission (2013). Opening up Education: Innovative teaching and learning for all through new Technologies and Open Educational Resources. [COM(2013) 654 final] [see: http://eurlex.europa.eu/legalcontent/EN/TXT/PDF/?uri=CELEX:52013DC0654\&from=EN]

[5] European Commission (2011). Supporting growth and jobs - an agenda for the modernisation of Europe's higher education systems. [COM/2011/0567 final] [see: http://eur-lex.europa.eu/legalcontent/EN/TXT/?uri=celex:52011DC0567]
[6] Gaskell, A., \& Mills, R. (2014). The quality and reputation of open, distance and e-learning: what are the challenges? Open Learning, 29 (3), pp. 190-205.

[7] Glass, C. R, Shiokawa-Baklan, M. S, Saltarelli, A. J. (2016). Who Takes MOOCs? New Directions for Institutional Research, 2015(167), pp. 41-55.

[8] Hansen, J. D., \& Reich, J. (2015). Democratizing education? Examining access and usage patterns in massive open online courses. Science, 350(6265), pp. 1245-1248.

[9] Henderikx, M. A., Kreijns, K., \& Kalz, M. (2017). Refining success and dropout in massive open online courses based on the intentionbehaviour gap. Distance Education, 38, pp. 353-368.

[10] Margaryan, A., Bianco, M., \& Littlejohn, A. (2015). Instructional quality of massive open online courses (MOOCs). Computers \& Education, 80, pp. 77-83.

[11] Moore, M. G. (1989). Three types of interaction. The American Journal of Distance Education, 3(2), pp. 1-7.

[12] Nandi, D., Hamilton, M., \& Harland, J. (2012). Evaluating the quality of interaction in asynchronous discussion forums in fully online courses. Distance Education, 33(1), pp. 5-30.

[13] Nyberg, D. (1975). The philosophy of open education. London: Routledge and Kegan Paul.

[14] OECD (2016). Education at a Glance 2016: OECD Indicators. Paris: OECD Publishing.

[15] Onah, D. F., Sinclair, J., \& Boyatt, R. (2014). Dropout rates of massive open online courses: behavioural patterns. EDULEARN14 Proceedings. pp. 5825-5834.

[16] Padilla-Rodriguez, B. C., \& Armellini, A. (2015). Expanding the interaction equivalency theorem. The International Review of Research in Open and Distributed Learning, 16(3), s.p.

[17] Peter, S., \& Deimann, M. (2013). On the role of openness in education: A historical reconstruction. Open Praxis, Vol. 5(1), pp. 714.

[18] Reich, J. (2015). Rebooting MOOC research. Science, 347(6217), pp. 34-35.

[19] Shah, D. (2018, January 22). A Product at Every Price: A Review of MOOC Stats and Trends in 2017. Class Central. Retrieved from https://www.class-central.com/report/moocs-stats-and-trends-2017/ [on 25 April 2018].

[20] Sher, A. (2009). Assessing the relationship of student-instructor and student-student interaction to student learning and satisfaction in web-based online learning environment. Journal of Interactive Online Learning, 8(2), pp. 102-120.

[21] Stracke, C. M. (2017a). The Quality of MOOCs: How to improve the design of open education and online courses for learners? Proc. 4th International Conference, Learning and Collaboration Technologies (HCII 2017), Part I, LNCS 10295, pp. 285-293.

[22] Stracke, C. M. (2017b). Why we need High Drop-out Rates in MOOCs: New Evaluation and Personalization Strategies for the Quality of Open Education. Proc. 17th IEEE International Conference on Advanced Learning Technologies (ICALT 2017), pp. 13-15.

[23] Tawfik, A. A., et al. (2017). The nature and level of learner-learner interaction in a chemistry massive open online course (MOOC). Computers in Higher Education, 29. p. 411-431.

[24] UNESCO (2012). 2012 Paris OER Declaration. 2012 World Open Educational Resources (OER) Congress. Paris: UNESCO.

[25] Veletsianos, G., \& Shepherdson, P. (2016). A Systematic Analysis and Synthesis of the Empirical MOOC Literature Published in 20132015. The International Review of Research in Open and Distance Learning, 17(2), 198-221.

[26] World Bank (2016). World Development Report 2016: Digital Dividends. Washington, DC: World Bank.

[27] Zimmerman, T. D. (2012). Exploring learner to content interaction as a success factor in online courses. The International Review of Research in Open and Distributed Learning, 13(4), pp. 152-165. 